\title{
THE
}

\section{Prospect Theory and Tenure Reform: Impacts on Forest Management}

\author{
Karen A. Sullivan \\ Emi Uchida \\ University of Rhode Island, euchida@uri.edu \\ Thomas W. Sproul \\ University of Rhode Island, sproul@uri.edu \\ Jintao Xu
}

Follow this and additional works at: https://digitalcommons.uri.edu/enre_facpubs

\section{The University of Rhode Island Faculty have made this article openly available.}

Please let us know how Open Access to this research benefits you.

This is a pre-publication author manuscript of the final, published article.

Terms of Use

This article is made available under the terms and conditions applicable towards Open Access Policy Articles, as set forth in our Terms of Use.

\section{Citation/Publisher Attribution}

Sullivan, K. A., Uchida, E., Sproul, T. W., \& Xu, J. (2018). Prospect Theory and Tenure Reform: Impacts on Forest Management. Land Economics, 94(3), 405-424. doi: 10.3368/le.94.3.405

Available at: http://dx.doi.org/10.3368/le.94.3.405

This Article is brought to you for free and open access by the Environmental and Natural Resource Economics at DigitalCommons@URI. It has been accepted for inclusion in Environmental and Natural Resource Economics Faculty Publications by an authorized administrator of DigitalCommons@URI. For more information, please contact digitalcommons-group@uri.edu. 


\title{
Prospect Theory and Tenure Reform: Impacts on Forest Management
}

\author{
Karen A. Sullivan* \\ U.S. Environmental Protection Agency \\ 1200 Pennsylvania Avenue, N.W. \\ MC 5101T \\ Washington, DC 20460 \\ Emi Uchida \\ Department of Environmental and Natural Resource Economics \\ Kingston Coastal Institute \\ 1 Greenhouse Road \\ University of Rhode Island, Kingston, RI 02881 \\ Thomas W. Sproul \\ Department of Environmental and Natural Resource Economics \\ Kingston Coastal Institute \\ 1 Greenhouse Road \\ University of Rhode Island, Kingston, RI 02881 \\ Jintao Xu \\ China Center for Energy and Development \\ The National School of Development, Peking University \\ Beijing 100871, P. R. China
}

*Corresponding author. Karen Sullivan is an economist in the Office of Land and Emergency

Management at the U.S. Environmental Protection Agency. Emi Uchida is an Associate Professor and

Thomas Sproul is an Associate Professor in the Department of Environmental and Natural Resource

Economics at the University of Rhode Island. Jintao Xu is Professor and Director, China Center for Energy and Development, National School of Development at Peking University in Beijing, China. The views expressed in this paper are those of the authors and do not necessarily reflect the views or policies of the U.S. Environmental Protection Agency. This project was supported in part by the National Science Foundation [NSF] IGERT grant DGE-0504103 to the University of Rhode Island Coastal Institute, the NSF Social Behavioral and Economic Sciences Doctoral Research Dissertation Improvement Grant SES0921207, the NSF East Asia and Pacific Summer Institute (OISE-0913708), the Russell Sage Foundation Small Grant Program in Behavioral Economics, the URI College of Environment and Life Sciences CARES McIntire-Stennis and the China and Inner Asia Council of the Association for Asian Studies Small Grant. 


\begin{abstract}
We examine the role of risk and time preferences in how forest owners respond to forest certification. We test hypotheses from a two-period harvest model derived from prospect theory in the context of Fujian, China, where new forest certification started in 2003. Using survey and field experiment data, we find that certification resulted in reduced harvesting, and the effect was larger for households who are more risk averse and exhibited distorted probability weighting. In contrast, households who are loss averse increased harvesting after certification. These findings suggest that diverse individual preferences may be a source of impact heterogeneity for forest certification.
\end{abstract}




\section{Introduction}

Forest degradation persists throughout much of the world (FAO 2010). The cause of this continued degradation is complex and multifaceted but over the last two decades insecure rights to ownership and use of forest resources, especially in developing countries, has been recognized as a key cause (e.g., White and Martin 2002; Sunderlin et al. 2005; Larson et al. 2013; Robinson et al. 2014). Rights to ownership and use of forest resources are often undefined, contested, overlapping or unenforced. Without secure rights forest holders have few incentives to invest in managing and protecting their forest resources. This realization has stimulated the current trend in forest policy toward strengthening property rights for forest resources by land property rights and titling programs, which transfer rights from the state to communities and individuals to manage and extract forest resources (Ellsworth and White 2004; FAO 2011). However, property rights and titling programs have not consistently led to the intended sustainable resource use and management, particularly in developing countries. On one hand, some studies have found empirical evidence that more secure land rights facilitated investment in trees, such as in Ghana (Besley 1995) and Ethiopia, (Holden et al. 2009). At the same time, other studies have found that tenure reforms have not led to their intended consequence of sustainable resource management, for example, in Indonesia (Barr 2001), Russia (White and Martin 2002), and elsewhere (Ostrom 1990; Bromley 1991; Alston et al. 1999; Bohn and Deacon 2000; Walker et al. 2002; Sunderlin et al. 2008).

The purpose of this study is to examine the role of individual preferences in how resource owners respond to property rights reforms, using a model derived from cumulative prospect theory (Tversky and Kahneman 1992). Households making forest management decisions face many uncertainties through prices, growth and quality of retained stands, outbreaks of disease, 
pest infestations, forest fire, extreme weather events, and most importantly in the context of this study, through redistribution or expropriation of forest land. Furthermore, decisions about forest management often involve a long time horizon. As such, households' risk and time preferences play an important role in their forest management decisions (Newman 2002; Tahvonen and Kallio 2006; Couture and Reynaud 2008). For example, a more patient or less risk averse individual may harvest their forest plot less, deferring harvest income to a future period. Changes in property rights can affect forest management directly (Johansson and Lofgren 1985) but the reform effects can interact with individual time and risk preferences, affecting the net effect of how households change their forest management practices. For example, even if households are given secure property rights, those with a strong preference for current benefits may have the incentive to harvest forest resources faster.

Failure to recognize the impacts of households' risk and time preferences may result in outcomes that policymakers sought to prevent. These factors become even more important in poor economies because risk and time preferences are often found to be correlated with wealth: the poor tend to be more risk averse and have a stronger time preference for the present (e.g., Besley1995; Holden et al. 1998; Nielsen 2001; Yesuf and Bluffstone 2009; Tanaka et al. 2010.) To our knowledge, no previous study has directly examined how risk and time preferences affect household responses to property rights reforms. Additionally, we seek to contribute to the empirical literature measuring the impact of land property rights and titling programs on natural resource management. Several studies have documented the effects on land-related investment (e.g., Brasselle et al. 2002; Do and Iyer 2008; Deininger et al. 2011; and Grimm and Klasen 2015), agricultural productivity (e.g., Banerjee et al. 2002), access to credit (e.g., Place and Migot-Adholla, 1998; Carter and Olinto 2003), and migration (DeJanvry et al. 2015). However, 
few empirical studies examine the effect of property rights and titling programs on forest management. This study examines the effect of a land certification program on tree harvesting decisions using parcel-level panel data and employing parcel fixed effects.

We begin by constructing a simple two-period model of optimal forest management under uncertainty based on prospect theory, taking account of risk preferences, time preference, and risk over property rights of forests. Consistent with the situation on the ground in China, we model forest tenure security as a reduction of expropriation risk (as in, e.g., Jacoby et al. 2002; Goldstein and Udry 2008). We derive comparative statics to predict signed effects on harvesting efforts from the reform and from changing preferences, and higher order interaction effects of individual preferences when subject to the reform. We then test empirically both hypothesized and ambiguous effects, using original survey and field experiment data from Fujian Province, China, where a large-scale reform of forest land tenure took place from 2003 to 2007. Under this reform, the responsibilities of forest planting and management were transferred from collective management (by townships and villages) to households. This transfer of responsibility was accompanied by a forest certificate, a legal document establishing a household's rights to a specific forest area.

We combine the risk and time preference field experiment data collected from 103 households in Fujian Province with panel survey data collected from the same households. The panel data set contains data for three years, 2000 (before the reform), 2005 (during the reform) and 2008 (after the reform), and a measurement of harvest for each plot as the outcome variable of interest. Although the risk and time preference data were collected after the reform, this study provides one of the first empirical evidence on how those preferences interact with natural 
resource management and policy. We use these data to estimate the above effects in a differencein-differences framework.

Results show that risk and time preferences impact households' forest management responses to forest plot certification. Specifically, in response to forest certification more risk averse households reduced harvesting more, while more loss averse households increased harvesting more. Beyond these findings, our study is unique because we link time and risk preferences elicited using real-money experiments (following Tanaka et al. (2010) and Liu (2013)) to actual natural resource management behavior, which few studies have previously done (Godoy et al. 2001; Liu 2013).

The remainder of this paper is organized as follows. Section 2 provides a background for China's Forest Tenure Reform and Section 3 introduces a simple prospect theoretic model of forest plot management to derive comparative statics hypotheses. Section 4 introduces our panel data set and identification strategy, and Section 5 explains the experimental elicitation process for uncovering risk and time preferences of the subjects. Section 6 gives the empirical results and robustness checks and Section 7 concludes.

\section{China's Forest Tenure Reform}

Historically, land allocation has played an important role in China as a key capital for livelihood that has been shared based on strong equity principles in rural areas (Carter and Yao 1998; Jacoby et al 2002). Village land allocation also has functioned as a substitute for missing land markets in China and several other countries (Holden et al. 2013). Village leaders allocated land according to household size, taking into consideration of variation in quality of land, and redistributed primarily based on changes in household size to ensure equity. This possibility of 
reallocation imposed a real risk of land expropriation (Jacoby et al. 2002). A major change in land tenure came about with the Household Responsibility System from the late 1970s, which gave households contracts to their land for a longer period. This reform primarily focused on agricultural land and enhanced private production activities, stimulating strong economic growth since the 1980s (Holden et al. 2013). A series of studies predicted 'hazards of expropriation' to frequency and intensity of land redistributions or other proxies in China and found that landspecific investment such as organic fertilizer increased after the expropriation risk was reduced with the Household Responsibility System (Brandt et al. 2004; Jacoby et al. 2002; Rozelle et al. 2002).

Forest tenure systems in China also have undergone a series of significant changes over the past 60 years, as detailed in $\mathrm{Xu}$ and Jiang (2009). Tenure for forestland changed back and forth between 'collectives', in which decisions are made by the village leadership, and 'private management' by the households (Liu and Edmunds 2003; Holden et al. 2013). Collectivization of non-state owned forests began in 1956. Under collectivization, administrative villages functioned as the legal owners of collective forests and households had little active participation in management and no links among their use rights, responsibility for forest management, and benefits from forests (Dachang 2001). The reform through the Household Responsibility System primarily focused on agricultural land and was mixed and less positive on forestland at the time (Holden et al. 2013). Collectivization remained dominant until the 1980s when the first major wave of tenure reform occurred under the "Three Fixes" policy, a reform aimed at transferring the responsibility of forest planting and management from the collective to households (Miao and West 2004). By 1986, nearly 70\% of collectively owned forest land in China had been transferred to rural household management, but unsustainable logging in the late 1980s led the 
government to return a large portion of forest land to collective management (Hyde et al. 2003). Even when forestland was allocated as family plots under the earlier wave of reform, no clear duration was given at first, and forestland that was not used or planted was recovered by the collectives and was either redistributed to other households, leased out, or converted back to collective management (Holden et al. 2013). Liu and Edmunds (2003) found that this type of early reform did not lead to more investment, but instead discouraged replanting after harvesting. Clearly, these frequent policy changes created land redistributions among the households (Holden et al. 2013). In addition to China, land redistributions have created tenure insecurity not just in China but in other developing economies such as Ethiopia (Holden and Yohannes 2002; Mekonnen et al. 2013).

In the early 2000s, limited forest tenure rights became increasingly recognized as a cause of a political crisis in the forestry sector and a key impediment to sustainable forest management, increased timber production, and poverty alleviation. As a result, the State Forestry Administration encouraged provinces to implement forest tenure reforms, and by mid-2003 the central government devised the "Resolution on the Development of Forestry," as known as the "No. 9 Policy" (Xu et al. 2010). By 2007, 14 provinces had begun implementation of the reform.

The new forest tenure reforms provide a national-level policy framework that aims to 1) clarify property rights; 2) issue a certificate to each household for the verification of scope and rights; 3) grant harvesters more freedom to manage their contracted forests; and 4) ensure harvesters' rights to benefit from their forests (Wang et al. 2012). The decisions regarding tenure arrangements during this reform required a two-thirds majority vote by the village representative committees or assemblies. The certification defined the boundary of the forest plots, specified the duration of the rights (30 to 70 years) and expanded the rights to include 
transfer, inheritance and mortgaging (Xu and Jiang 2009). ${ }^{1}$ Before the certification, there were no well-defined boundaries and no specific duration or much shorter duration (5 to 15 years) of the use rights (Liu and Lixia 2009). Therefore households faced a non-trivial expropriation risk at any time. This institutional background motivates our hypothesis that the effect of certification may interact with households' risk preferences.

This study utilizes original household and village survey data collected in Fujian Province, which has been a leader in the recent forest tenure reform following the unsuccessful reforms in the 1980s. Fujian's system of the time, using "paper shares" of collective forests, limited the distribution of collective forest land for household management and led to a lagging forest economy, despite forest land covering over $60 \%$ of total provincial land area. The system was also plagued by enforcement problems and lack of cooperation from harvesters, leading to growth of forest fires in the 1990s, many of which were said to be caused by harvesters and rural households (Xu and Jiang 2009). These historical problems led Fujian to take a leadership role in implementing the recent forest tenure reforms in 2003, making the province an ideal setting to test our hypotheses by allowing us to collect panel data for analyses of reform impacts. Moreover, prior to the reform, more than $90 \%$ of its forests were collectively owned, making it representative of a major collective forest province. These settings make Fujian an appropriate site to study the impact of certification.

\section{A Model of Forest Harvesting with Prospect Theoretic Preferences}

In this section, we construct a simple model of optimal forest management under uncertainty, taking account of risk preference, time preference, and risk over property rights of forests. The model motivates our empirical approach in developing comparative statics predictions, as well as 
a need for empirical resolution of ambiguous results. In modeling the effect of tenure security, the standard approach in the classical natural resource economics literature is to differentiate full property right (sole ownership) vs. no property rights (open access) in a resource harvesting decision (e.g., Gordon 1954; Hardin 1968). We take a different approach by modeling forest certificates as reducing land expropriation risks in the future and hence benefits from future harvests. This modeling approach has been taken, for example, in agricultural and development economics to model investment decisions when future returns from investment are risky because there is a positive expropriation risk from insecure property rights (e.g., Jacoby, Li and Rozelle 2002; Goldstein and Udry 2008.)

Consider a forest owner with reference dependent preferences who maximizes the present value of utility from harvest, with net discount factor, $\rho$. We collapse the intertemporal problem into a two-period problem, where only the second period is discounted. In the first period, the forest has size, $\bar{H}$, and the owner can harvest, $H_{1} \in[0, \bar{H}]$, with the remainder, plus growth, $g$, being harvested in the second period. Thus, $H_{2}\left(H_{1}\right)=\left(\bar{H}-H_{1}\right)(1+g)$ if the forest plot is not expropriated, but $H_{2}=0$ if the plot is expropriated. Due to the lack of outside investment opportunities and credit markets available to households in our empirical sample, we assume that the value from early harvest is only consumption utility, and that there is no mechanism for investing the proceeds of excess early harvest for future gains.

The forest plot manager maximizes a value function over current period (1) and future period (2) harvests:

$$
\begin{aligned}
\max _{H_{1}} V\left(H_{1}\right) & =v_{1}\left(H_{1}\right)+\rho \cdot E_{\pi}\left[v_{2}\left(H_{2}\right)\right] \\
& =H_{1}^{1-\sigma}+\rho \cdot\left(r^{1-\sigma}+E_{\pi}\left[v\left(H_{2}, r\right)\right]\right)
\end{aligned}
$$


where

$$
v\left(H_{2}, r\right)=\left\{\begin{array}{lll}
\left(H_{2}-r\right)^{1-\sigma} & \text { if } & H_{2} \geq r \\
-\lambda\left(r-H_{2}\right)^{1-\sigma} & \text { if } & H_{2}<r
\end{array}\right.
$$

and where $\sigma \in[0,1)$ is a fractional exponent indicating curvature of the value function and $\lambda>1$ is the loss aversion coefficient indicating the severity of the kink at the reference point. ${ }^{2}$ The expectation under $\pi$ refers to distorted probability weights (aka "decision weights") consistent with prospect theory, which overstate (understate) the probability of unlikely (likely) events (Tversky and Kahneman, 1992). Note that the value function, $v$, is the standard prospect theory model with minor adaptation of the exponent to be consistent with our empirical specification following Liu (2013). We denote as $p_{K}$ the probability of keeping the plot private in the future period (i.e., no expropriation), and $p_{L}=1-p_{K}$ as the probability of loss due to expropriation. $\pi_{K}$ and $\pi_{L}$ are the corresponding decision weights. While our specification here does not require a specific functional form, our empirical specification can serve as an example to clarify the nature of probability weights. We define $\pi(p)=\exp \left(-(-\ln p)^{\alpha}\right)$, which is Prelec's (1998) axiomatically-derived probability weighting function.

Choosing the reference point, $r$, can be easy or challenging depending on the setting. In any inter-temporal model, the reference point for future periods will be based on expectations, and these expectations will be a function both of the owner's own actions and of the distorted probability weights. For internal consistency in our model, we model the reference point as $r=E_{\pi}\left[H_{2}\right]$. The interested reader may consult Koszegi and Rabin (2009) for an overview of 
dynamic considerations with reference dependent preferences, though their paper focuses much more closely on how and when information arrives than the present article.

Following this specification, $r=E_{\pi}\left[H_{2}\right]=\pi_{K} \cdot H_{2}\left(H_{1}\right)$, so we have:

$$
\begin{aligned}
E_{\pi}\left[v\left(H_{2}, r\right)\right] & =\pi_{K} \cdot\left(H_{2}-r\right)^{1-\sigma}-\pi_{L} \lambda r^{1-\sigma} \\
& =\pi_{K} \cdot\left(\left(1-\pi_{K}\right) H_{2}\right)^{1-\sigma}-\pi_{L} \lambda\left(\pi_{K} H_{2}\right)^{1-\sigma}
\end{aligned}
$$

allowing us to rewrite the objective function more clearly:

$$
\begin{aligned}
\max _{H_{1}} V\left(H_{1}\right) & =H_{1}^{1-\sigma}+\rho \cdot\left(r^{1-\sigma}+E_{\pi}\left[v\left(H_{2}, r\right)\right]\right) \\
& =H_{1}^{1-\sigma}+\rho \cdot\left(\pi_{K}^{1-\sigma} H_{2}^{1-\sigma}+\pi_{K} \pi_{L}^{1-\sigma} H_{2}^{1-\sigma}-\lambda \pi_{L} \pi_{K}^{1-\sigma} H_{2}^{1-\sigma}\right) \\
& =H_{1}^{1-\sigma}+\rho \pi_{K}^{1-\sigma} H_{2}^{1-\sigma} \cdot\left(1+\pi_{K}^{\sigma} \pi_{L}^{1-\sigma}-\lambda \pi_{L}\right) .
\end{aligned}
$$

This derivation implies, reasonably, that $\pi_{L}$ must be below some threshold level, as a function of $\sigma$ and $\lambda$, in order for the second term to be positive enough that an interior solution might be found. Otherwise, the loss averse plot manager will simply choose the maximum harvest in the first period, leaving nothing for the future. There are also combinations of these parameters (for example: low discounting, low risk, rapid growth), such that the other corner solution can be reached, where all harvest is deferred $\left(H_{1}=0\right)$. Assuming an interior solution, the resulting necessary first order condition for the choice of $H_{1}$ is:

$$
\left(H_{1}^{*}\right)^{-\sigma}-(1+g)^{1-\sigma}\left(\bar{H}-H_{1}^{*}\right)^{-\sigma} \cdot \rho \pi_{K}^{1-\sigma} \cdot\left(1+\pi_{K}^{\sigma} \pi_{L}^{1-\sigma}-\lambda \pi_{L}\right)=0
$$

and the second derivative is negative everywhere. Thus, the value of $H_{1}^{*}$ satisfying the first order condition above is a unique interior maximum, provided parameters are such that a corner solution is not reached. 
Applying the implicit function theorem yields comparative statics results for both preference and policy parameters. Assuming that the decision weight on expropriation risk, $\pi_{L}$, is monotone increasing in the true probability, $p_{L}$, then $\partial H_{1}^{*} / \partial p_{L}>0$ for some values of $\pi_{L}$, $a, \sigma$, and $\lambda$, but not others, so early period harvest may or may not be increasing with expropriation risk and with the degree of distortion from decision weights. We predict that a rising discount factor will decrease early harvest $\left(\partial H_{1}^{*} / \partial \rho<0\right)$, and a higher loss aversion coefficient will increase early harvest $\left(\partial H_{1}^{*} / \partial \lambda>0\right)$. The risk aversion parameter, $\sigma$, is equivalent to the coefficient of relative risk aversion from a CRRA utility function, so its comparative static measures the effect of curvature of the value function on early harvest, all else equal. This effect is not sign-able without further assumptions, so we leave it as an empirical question to resolve later.

We also test higher order interaction terms in the empirical section below. In particular, we ask how do risk and time preferences interact with policy, possibly making the effects of forest tenure reform different for different managers? Extending the comparative statics above, we would predict that $\partial^{2} H_{1}^{*} / \partial \lambda \partial \pi_{L}<0$ if $\partial H_{1}^{*} / \partial \pi_{L}>0$, i.e., among plots subject to tenure reform those plots with more loss averse managers will exhibit a weaker treatment effect, meaning larger, or more frequent, harvests than their less loss averse counterparts. Our model does not give definitive signs for $\partial^{2} H_{1}^{*} / \partial \sigma \partial \pi_{L}$ or $\partial^{2} H_{1}^{*} / \partial \pi_{L}^{2}$ (the latter being the interaction of reform policy with probability weights), but it does predict that $\partial^{2} H_{1}^{*} / \partial \rho \partial \pi_{L}$ will have the same sign as $\partial H_{1}^{*} / \partial \pi_{L}$. It should be noted that all unambiguous comparative statics predictions are monotone over the parameter space. This means that, conditional on the other parameters, they 
can be used to predict probability of corner solutions. So, for example, the prediction that $H_{1}^{*}$ is unambiguously increasing in some parameter, means higher levels of that parameter also predict more corner solutions of maximum harvest $\left(H_{1}^{*}=\bar{H}\right)$, and fewer corner solutions of deferred harvest $\left(H_{1}^{*}=0\right)$, across a population of harvesters where other parameters are heterogeneous.

For those comparative statics where we have made predictions, we test them in the Results section below, and for those where no ex ante prediction of the direction of an effect is possible, we use our empirical results as a guide to inform future research.

\section{Data, Definitions, and Descriptive Statistics}

Our study area includes two counties in Fujian, China-Datian County in central Fujian and Sanming City in the west. Forest land covers more than $60 \%$ of the provincial land area, and is a growing source of income for households living in rural forested areas. Based on a larger survey of 600 households in Fujian, forestry accounted for 8.98\% of household income in 2006, a $3.71 \%$ share increase since 2000 , prior to the reform (Xu et al. 2010). Other income sources include agriculture (10.28\%), livestock (9.21\%), off-farm (65.14\%), and other $(6.36 \%)$. In our study area and in rural China in general, credit markets are missing or incomplete at best, and most households have limited access to formal loans (Ong 2012). This motivates our approach of elicitating a measure for pure time discount rate.

\section{Household survey}

Our household panel data set includes data for 104 households spanning two counties, Sanming City and Datian County, and 10 villages in Fujian Province for three years: 2000 (before the 
reform), 2005 (during the reform) and 2008 (after the reform). ${ }^{3}$ Data for the years 2000 and 2005 were collected in 2006 by a research team from Peking University, Gothenburg University, and Forest Trends, and data for the year 2008 was collected in 2009 by researchers from Peking University and the University of Rhode Island. We collected data on harvest and household-level attributes such as income and plot ownership, as well as plot-level attributes including distance from the nearest road and primary forest type (bamboo or other). During the 2009 data collection, households were asked to complete the survey and to participate in two real-money decision-making tasks, our risk and time preference experiments. All households completed the survey but one household chose not to participate in the decision-making tasks, so their data were discarded, leaving a sample of 103 households. Each household was paid 15 yuan to complete the survey plus their earnings in the decision-making tasks. Descriptive statistics are available in Table 1.

For our analysis, we construct a balanced panel data set by using only those forest plots that were managed by the household in 2000, 2005 and 2008, so that we have pre- and postreform data for every plot in the analysis. The plot level analysis is appropriate because households were given certification at the plot level in the reform process. In our sample, $16 \%$ of the households have both forest plots that are certified and plots that are not certified. The resulting sample includes 295 plots, owned by 87 households. ${ }^{4}$ Of those, 88 plots (owned by 26 households) constitute the treatment group, having received forest certificates during the reform (2003 - 2007), and the remainder make up the control group (no certificate by 2008). As of mid2005, 36 of the treated plots had received certificates, but we find no statistically significant evidence of an "early treatment effect" relative to the rest of the plots. Of the 88 treatment plots 
(and 207 control plots), we have data on distance from home and road only for 75 treatment plots (and 145 control plots).

In 2000, an average household had 4.9 household members, a head of household who was 46 years old with 4.7 years of education, and total assets of 10,430 yuan. On average each household held a total of 2.3 hectares of forest land. The average forest plot had an area of 0.94 hectares, was 1.43 kilometers from home, and was 0.87 kilometers from the road. Bamboo was the primary forest type of $37 \%$ of the plots.

To capture household forest management, we define a binary variable which equals 1 if the household spent any harvest effort on a given plot in a given year. In the survey, the respondents gave an estimate of the amount of labor spent in harvesting on each plot in each period, including family labor, labor exchanged with other households, and hired labor. Because of the frequency of zeros in the data and the potential noise in the recall-based estimates, we elected to use a binary dependent variable for harvest based on the reasoning that recall of whether harvest occurred was more likely to be accurate than recall of the exact amount of harvesting labor effort. ${ }^{5}$ Therefore, 'harvest' means whether any harvesting effort has been spent. Of the three types of forests in our data set—bamboo, evergreen coniferous and hardwood trees - our field observations suggest that bamboo plots are more likely to be almost completely harvested in a given time period, whereas plots with other tree types are not.

\section{Elicitation of Risk Preferences}

To elicit risk preferences, we followed the experimental design developed by Tanaka et al. (2010) and later modified by Liu (2013), both of whom expand the classic Accept/Reject lottery experiments of Holt and Laury (2002) to incorporate prospect theory. Prospect theory is more 
flexible than standard, expected utility specifications in that it allows for the possibility that an individual may be risk averse, risk neutral or risk seeking, depending on whether choices involve gains or losses and whether the probabilities of gains or loss are large or small (Kahneman and Tversky 1979). Under prospect theory, an individual's risk preferences are described by three measures: the degree of risk aversion (curvature of the value function), $\sigma$, the degree of loss aversion (severity of the kink in the value function at the reference point, $r$ ), $\lambda$, and a nonlinear probability weights/distortion measure, $\alpha .{ }^{6}$ We use these three parameters to represent each household's risk preferences in our empirical analysis, consistent with the value function and probability weighting functions given in the Model section above.

To elicit these parameters experimentally, we followed the procedures of Liu (2013). Documentation of all experimental materials can be found in the Appendix. According to her specification, the parameter $\sigma$ describes the curvature of an individual's value function, but we do not impose a range of values when eliciting preferences: an individual is described as risk averse when $\sigma>0$, risk neutral when $\sigma=0$, and risk loving when $\sigma<0$. The parameter $\alpha$ is a non-linear probability weighting measure, from the model of Prelec (1998); when $\alpha<1, \pi(\mathrm{p})$ has an inverted S-shape, indicating that an individual tends to overweight low probabilities and underweight high probabilities, as in Tversky and Kahneman (1992). This model reduces to expected utility theory (with an S-shaped utility function) when $\alpha=1$ and $\lambda=1$.

In the experiment, participants were asked to choose between sets of lottery options. For example, Option A might offer a $30 \%$ chance of receiving 20 yuan and a $70 \%$ chance of receiving 5 yuan, while Option B offers a 10\% chance of receiving 34 yuan and a $90 \%$ chance of receiving 2.5 yuan. A total of 35 choices, divided between three series were asked. Monotonic switching was enforced, meaning that once the subject switched to option B they were not 
allowed to switch back to option A, to eliminate the possibility of inconsistent choices and to make the task easier for participants to understand. Once the subject had completed the entire series of choices, one question was chosen randomly for payoff. The payoffs ranged from a loss of 10 yuan to a gain of 850 yuan, which is roughly half a month's pay in rural Fujian, and the average payoff was 27 yuan, about half a day's wage (CSY 2009). Following a standard practice in this type of experiment, the risk game was calibrated in such a way that the maximum loss was less than the "showup fee" paid to all participants, with a reference point of $r=0$.

In our sample, the average estimated values for $\alpha$ and $\lambda$ are 0.73 and 6.02 , respectively, and both are statistically different from 1 at the $1 \%$ significance level, implying that our experimental subjects, on average, are best represented by the probability weighting and loss aversion of prospect theory. The average derived value of $\sigma$ is 0.40 , indicating on average households in the sample exhibit risk aversion (the median value is 0.4 ). For comparison, values estimated here for $\sigma$ and $\alpha$ are very similar to those found by Liu (2013) in a sample of Chinese farmers $(0.48,0.69)$ and by Tanaka et al. $(2010)$ in a sample of Vietnamese farmers $(0.59,0.74)$. Additionally, our mean estimated value of $\sigma=0.42$ is within the range of constant relative risk aversion measured in choose lottery experiment conducted in developing countries, which range from 0.17 in Uganda to 0.84 in India (Cardenas and Carpenter 2008). For loss aversion, the average estimated value for $\lambda$ in our sample is approximately twice as high as the values in Liu (2013) of 3.47 and Tanaka et al. (2010) of 2.63, but the median value is 2.04 , which is below the estimated figure of 2.25 from Tversky and Kahneman (1992). A few very highly loss averse households both make the average higher in our sample, and likely decrease the efficiency of our loss aversion parameter estimates. To ease the interpretation of the coefficient on $\alpha$, which has a kink at 1 , we create a dummy variable which a dummy variable equal to 1 indicates an individual 
who puts excessive decision weight on small probabilities $(\alpha<1)$ and a dummy variable equal to 0 indicates an individual who does not overweight small probabilities $(\alpha \geq 1)$.

One caveat is that we used preference parameters derived from field experiments occurring after the households' forest management experience, which may have affected their preferences. Unfortunately, we cannot test for such effects with our current data. However, Meier and Sprenger's (2010) study of 250 individuals in Massachusetts found that although some subjects show variation in their time preference in one year's time, individual level correlations over time were strongly significant and the mean change in the individual discount factor and present-bias parameter was small. Further, they found that changes in income, unemployment, family composition or future liquidity did not predict the differences in time preferences, nor was there correlation between demographics and preference instability. Several studies have also found no tendency for risk preferences to systematically increase or decrease over time and that measures taken at two different periods of time show acceptable correlations (Harrison et al. 2005; Sahm 2007; Andersen et al. 2008; Baucells and Villasis 2009; Reynaud and Couture 2012). We consider this justification that our approach is reasonable.

In addition to prospect theory risk preferences, we also elicited time preferences in a manner consistent with Tanaka et al. (2010). Since elicited time preferences are not significant predictors in our regression analysis, details of the elicitation method and summary statistics for the time preference parameters can be found in Appendix Table A1. ${ }^{7}$

\section{Empirical Framework}

Our empirical objective is to identify how heterogeneity in households' time and risk preferences may impact the average effect of forest plot certification on household forest management. A 
simple comparison of changes in forest management between plots that received and did not receive certification demonstrates that there is a correlation between certification and forest management, but it would clearly be a mistake to jump from this association to the conclusion that certification impacts forest management because certification plots were not selected randomly (at least, the allocation process was not designed to be completely random). This potential nonrandom placement of certification (selection into treatment) could bias our estimates without proper controls.

There are some indications that the selection bias from nonrandom placement of certification may not be large in our context. As with other forest policies in China in which participation is often exogenous to the household's decision (e.g., Li et al. 2011), by regulation the decision to participate is to be made at administrative village level, not at natural village ("xiaozu") level. The share of forests to be managed by households and/or xiaozu, the number of certificates issued by year, are the decision of the administrative village by $2 / 3$ vote of the representative committee of the administrative village. By regulation, every household can be issued a forest certificate. In addition, comparison of plot and household characteristics between the two groups of plots demonstrates that they are similar in many respects, including plot area, distance from plot to home or the closest road, and the average slope of the plot. Table 1 shows summary statistics for key variables across treatment and control groups, both at the household level and the plot level. We tested for differences in means using a two-sided t-test ( $p$-values and confidence intervals for Table 1 can be found in Table A2 of the online Appendix). We found statistically meaningful differences in only two covariates: loss aversion (at the $10 \%$ level, $p=0.075$ ) and number of plots managed (at the $99.9 \%$ level, $p=0.0005$ ).

[ Table 1 about here ] 
While we include the t-test with respect to number of plots managed for consistency, it is not an appropriate test of sample balance, due to a form of base rate neglect. In essence, households managing many plots are much more likely to have at least one plot certified, even under a null hypothesis of random assignment at the plot level. We conducted a simulation test to control for this oversampling of households with multiple plots into the at-least-one-treated-plot group, and estimated a non-parametric $p$-value of 0.805 . This indicates no evidence that households managing more plots are able to influence plot level treatment effects away from "as good as randomly assigned." The details of this analysis are found in Section 2 of the online Appendix. As a further test of balanced covariates, we conducted a test for joint orthogonality (Hansen and Bowers, 2008, "HB") by linear regression of certification on the covariates. Based on the F statistic of $2.04(p=0.09)$, we are unable to reject the null of joint orthogonality. This result is best considered as further circumstantial evidence of balance in the covariates, because the test has a larger than nominal size (from HB p.223: "the nominal 0.05-level test has an actual size of about 0.37"). Because of this, our observed estimate of $p=0.09$ has an implied $p$-value around 0.50 (according to HB p.224, Figure 1).

Even given the above, there could still be some self-selection bias, especially conditioned on covariates we do not observe. If we do not account for these and other potentially systematic differences between certified and noncertified plots, we risk incorrectly attributing differences in measured forest management outcomes between those plots for which households received a forest certificate and plots for which households did not receive a forest certificate to certification when in fact differences may be due to initial differences in unobserved characteristics (e.g., entrepreneurial ability) between the two groups (Conning and Deb 2007). Unfortunately, this is a drawback of many econometric approaches. 


\section{Identification Strategy}

The outcome of interest is the harvesting decision in each year. Although the theoretical model involves interior choices in harvesting decisions, we find that our collected data are best suited to evaluating treatment effects with respect to the discrete yes/no choice of whether to harvest at all. That is, enough plots opted out of harvesting each year $(21 \%$ in $2000 ; 56 \%$ in 2008$)$ that a discrete choice model is more appropriate than least squares regression. Put another way, the problem parameters were not sufficient to induce interior choices for a large number of plots. We therefore model the discrete choice of whether or not the household harvested the trees on the plot in that year.

The treatment variable is whether or not the plot was certified as part of the reform. The reform was officially introduced in 2003, but our data revealed that about two thirds of the certification was done in 2005. Although we collected harvesting decision data for 2000, 2005 ad 2008, it was ambiguous from the data whether 2005 should be treated as pre-reform or postreform. ${ }^{8}$ We therefore choose to conduct a clear pre- vs. post-reform evaluation by focusing on two years: 2000 as the pre-reform year and 2008 as the post-reform year.

We employ several strategies to account for the possibility of treatment effects being contaminated by unobservable factors. We estimate a plot fixed effects linear probability model, evaluating the decision of forest owners to harvest that year or not. We use this model to estimate the effect of treatment (forest certification) as well as the interaction of treatment with risk and time preferences while controlling for time-invariant plot-level characteristics and group, time, village, and household fixed effects. The estimating equation is:

$$
\operatorname{Pr}\left(y_{i t}=1\right)=\alpha_{0}+\alpha_{1} D_{i t}+\beta\left(D_{i t} * P_{j}\right)+\theta_{i}+\eta_{t}+\varepsilon_{i t}
$$


which is estimated using a linear probability model on $y_{i t}$, the realized choice of whether or not to harvest in year $t^{9} D_{i t}$ is an indicator variable indicating treatment, namely that the plot was certified between 2001 and 2008 (approximately two thirds of treated plots were certified during 2005). $P_{j}$ are preference covariates for household $j$, and thus $\left(D_{i t} * P_{j}\right)$ represents the interaction of treatment with risk and time preferences to test our comparative statics predictions from Section 3. Finally, $\theta_{i}$ and $\eta_{t}$ are fixed effects at the time and plot levels and $\epsilon_{i t}$ is an error term.

\section{Empirical Results}

The plot fixed effects indicate that the average effect of certification on the treated plots is a $12 \%$ reduction in the probability of harvesting (Table 2, column 1). In addition, preferences lead to significant heterogeneous harvest decisions across plots, and preferences do interact with the certification treatment to produce significant heterogeneous effects (columns 2-4). In the case of risk aversion (curvature of the value function) and loss aversion (sharpness of the kink), the treatment interaction effect has the opposite sign. This means that more risk averse and more loss averse plot owners actually reverse course when certified; they react in the opposite direction relative to being uncertified, essentially canceling out the effects of their preferences on harvesting decisions.

[Table 2 about here]

The marginal effect of treatment interacted with the risk aversion parameter is estimated to be a decrease of 75 percentage points (columns 2 and 4). Similarly, the marginal effect of treatment interacted with the probability weighting dummy decrease probability of harvesting by 36 points. In contrast, the estimated marginal effect of the treatment interacted with the loss aversion parameter is an increase of 4 percentage points. Put another way, this result implies that 
the intended effect of certification (to reduce or delay harvest) is actually larger for more risk averse households and those who give higher weights on small probability events, but the effect is smaller (or even negative for certain ranges) for more loss averse households. We also find no significant effect of the hyperbolic discount rate parameter, which is not surprising given its low level in our sample (columns 3 and 4).

The way in which risk preference lead to significant heterogeneous treatment effects is further evident from the implied certification effects (Table 3). The certification effects are computed for different levels of the risk and loss aversion parameters and the probability weighting dummy, which is a dummy for individuals who overweight small probabilities. ${ }^{10} \mathrm{In}$ general, the certification treatment has the intended effect of reducing the probability of harvesting for households who are more risk averse and less loss averse. For example, the certification treatment led to a 49 point marginal reduction in probability of harvesting for households in the $75^{\text {th }}$ percentile of risk aversion and $25^{\text {th }}$ percentile of loss aversion (Panel B, top row, right column). In contrast, when the household is highly loss averse ( $75^{\text {th }}$ percentile), the certification encourages households to harvest more regardless of the probability weighting dummy. For example, certification led to a 42 point increase in the probability of harvesting (at the margin) for households in the $75^{\text {th }}$ percentile of the loss aversion parameter with a median risk aversion level and places higher weight on low probability events (Panel B, bottom row, middle column).

[Table 3 about here] 


\section{Effect of individual preferences on harvesting decisions}

One drawback of the main model (Table 2), however, is that plot fixed effects difference out any direct effect of risk and time preferences, leaving only the effect of risk preferences interacted with treatment identifiable. Time and risk preferences play an important role in forest resource management under uncertainty (e.g., Reed 1984, Blennow et al. 2014). However, the the literature offers few empirical estimates of the direct effect of individual preferences on natural resource management. Given this literature gap, we test for the time and risk preferences on harvest decisions directly using the pre-treatment data only in a linear probability model with village fixed effects. The hypotheses for these coefficients are derived from our theoretical model. We estimate the following equation:

$$
\operatorname{Prob}\left(Y_{i, t=2000}=1\right)=\alpha_{0}+\beta P_{j}+\gamma X_{i}+\delta Z_{j}+\varphi_{v}+\varepsilon_{i}
$$

where $X_{i}$ and $Z_{j}$ denote time-invariant characteristics at the plot and household levels, and $\varphi_{v}$ are village fixed effects. These results do not allow for plot or household-level fixed effects, and hence are descriptive in nature and should not be taken as cleanly identified.

After controlling for plot and household characteristics in the baseline year as well as village fixed effects, we find that the probability of harvesting in 2000 was higher for households who are more risk averse and who over-weight low probability events (Table 4). In contrast, we found that the harvest probability was lower for households who are more loss averse. This finding contradicts the predictions of our theoretical model, but the result may not be economically significant; the coefficient estimate for loss aversion is an order of magnitude smaller than the estimates for the other behavioral parameters, while the loss aversion parameter is measured on a scale $0.5-1.0$ orders of magnitude larger than the other behavioral parameters, on average. Moreover, the coefficient on discount rate was not significant, not supporting the 
theoretical prediction. A high standard deviation of the estimated discount rates may have contributed to this finding.

\section{[Table 4 about here]}

A few other household and plot characteristics were associated with harvesting decisions in the baseline year. The only plot-level characteristic with statistical significance was whether or not the household grew bamboo on the plot. The result suggests that households are more likely to harvest plots with bamboos, which is intuitive since some types of bamboos become mature enough to be harvested in a two to three-year cycle, much faster than other types of trees for harvesting. Interestingly, households who had higher values of livestock dying in 2000 were more likely to harvest. While we do not claim identification in this descriptive regression, this result suggests that harvesting decisions may be associated with consumption smoothing (e.g., Pattanayak and Sills 2001). Household's party membership or role as village cadre had no correlation with harvesting decisions in 2000.

Table 5 presents the plot fixed effect estimates compared against our comparative statics predictions from Section 3. Overall the estimates are consistent with the predictions where our model yielded definitive predictions, with one exception of the direct association between harvesting decision and the loss aversion parameter. A reasonable hypothesis is the simultaneous determination of the parameters making up risk preferences, but future work is needed to understand these cause-and-effect relationships exactly. Overall the estimates are quite useful in addressing ambiguous signs of modeled comparative statics.

[ Table 5 about here] 


\section{Robustness Checks}

To check the robustness of our results, we run three additional variations of the plot fixed effect equation: (i) using exponential discounting instead of hyperbolic and (ii) with explicit values of the probability weighting distortion parameter instead of dummies for high probability weight distortions, and (iii) including the years since certification as an additional covariate. We find that the patterns of statistical significance are stable across specifications. ${ }^{11}$

\section{Conclusion}

Despite their potential importance, the heterogeneity in response to property rights reforms due to individual preferences has not been studied adequately. Progress is constrained by a lack of data. Measures of outcomes (such as harvesting of timber, etc.) are difficult to come by and eliciting measurement of risk and time preferences is difficult (Frederick et al. 2002; Cardenas et al. 2008). Furthermore, previous studies on forest tenure issues often use proxies to measure tenure security that are either subjective or indirect and may not provide accurate measurements (Godoy et al. 1998; Godoy et al. 2001; Hagos and Holden 2006).

In this paper, we examined how preferences over time and risk affect household forest management responses to property rights reforms, using risk and time preference data from a field experiment and a panel household survey from Fujian, China. We first constructed a simple model of optimal forest management under uncertainty, taking account of risk preferences as described in prospect theory, time preference, and risk over property rights of forests. We then tested the model's comparative statics predictions empirically. To identify how risk and time preferences augment the effect of forest plot certification on forest management activities, we used a plot fixed effects model. 
Our results suggest that more secure tenure as a result of forest certification affects households' forest management decisions by reducing probability of harvest as a first-order effect. We found that risk (loss) aversion leads to more (less) harvesting in the absence of reforms, but that these distortions are reversed by the certification process. So, while risk (loss) averse households will respond more strongly (weakly) to certification, they are likely to do so in a manner which reduces heterogeneity relative to the pre-treatment period. We found inconclusive evidence of heterogeneous harvest effort or heterogeneous policy responses with respect to time preferences, consistent with prospect theory. However, the insignificant effect of time preference on harvest decisions may be a result of the short time frame covered by our elicitations: the longest period of time participants were asked to consider was 6 months, which may not reflect the longer term decisions required in forestry management.

As mentioned previously, one caveat is that we used preference parameters derived from field experiments occurring after the forest reform. Unfortunately, it is impossible to predict the potential effect of the reform on preferences. Certification is likely to result in an increase in selfperceived wealth contemporaneous with a decrease in immediate income under optimal management, two effects which might seem to predict parameter changes in opposite directions. Moreover, it is possible that evolution of the market conditions during the ten years of this study could affect risk preferences. At least, the empirical literature thus far has found that preference parameters are stable and strongly correlated over time, suggesting that our empirical approach is reasonable. Overall the results of this paper have implications for policymakers in China and elsewhere by informing how heterogeneity among households may impact the outcomes of property rights reforms. Even in cases where economic agents respond, on average, to a reform in the manner expected, there may be substantial heterogeneity in their responses and this 
heterogeneity may have welfare implications. Although this study is conducted in the context of forests, the general finding may apply to other natural resources such as fisheries or groundwater where strengthening property rights have not always shown success in the manner intended. 


\section{References}

Alston, L. J., G. D. Libecap and B. Mueller. 1999. Titles, Conflict, and Land Use: The Development of Property Rights and Land Reform on the Brazilian Amazon Frontier. The University of Michigan Press, Ann Arbor.

Anderson, S. Harrison, G.W., Lau, M. I., and Ruström, E.E. 2008. Lost in state space: are preferences stables? International Economic Review 49(3) 1091-1112.

Angrist, Joshua D. and Jörn-Steffen Piscke. 2009. Mostly Harmless Econometrics: An Empiricist's Companion. Princeton University Press.

Banerjee, Abhijit, Gertler, Paul, Ghatak, Maaitresh, 2002. "Empowerment and efficiency: Tenancy reform in West Bengal." Journal of Political Economy 110(2): 239-280.

Barr, C. 2001. Banking on Sustainability: Structural Adjustment and Forestry Reform in PostSuharto Indonesia. World Wildlife Fund Macroeconomic Program Office, Washington D.C and the Center for International Forestry Research, Bogor Indonesia.

Baucells, M. and Villasis, A. 2009. "Stability of risk preferences and the reflection effect of prospect theory." Theory and Decision 68(1-2):193-211.

Besley, T. 1995. "Property Rights and Investment Incentives: Theory and Evidence from Ghana." The Journal of Political Economy 103(5): 903-937.

Blennow, Kristina, Johannes Persson, Annika Wallin, Niklas Vareman, Erik Persson; Understanding risk in forest ecosystem services: implications for effective risk management, communication and planning, Forestry: An International Journal of Forest Research, Volume 87, Issue 2, 1 April 2014, Pages 219-228.

Bohn, H. and R. T. Deacon. 2000. "Ownership Risk, Investment, and the Use of Natural Resources." American Economic Review 90(3): 526-549.

Brandt, L., Rozelle, S., \& Turner, M. 2004. Local Government Behavior and Property Right Formation in Rural China. Journal of Institutional and Theoretical Economics (JITE) / Zeitschrift Für Die Gesamte Staatswissenschaft, 160(4), 627-662.

Brasselle, Anne-Sophie, Frederic Gaspart, and Jean-Philippe Platteau. 2002. "Land tenure security and investment incentives: puzzling evidence from Burkina Faso." Journal of Development Economics 67(2): 373-418.

Bromley, D. W. 1991. Environment and Economy: Property Rights and Public Policy. Basil Blackwell, Oxford. 
Cardenas, J. C. and J. P. Carpenter. 2008. "Behavioral Development Economics: Lessons from Field Labs in the Developing World." Journal of Development Economics Studies 44(3): 311-338.

Carter, Michael and Pedro Olinto. 2003. "Getting institutions right for whom? Credit constraints and the impact of property rights on the quantity and composition of investment." American Journal of Agricultural Economics 85: 173-186.

Carter, M. and Yao, Y. 1998. 'Property Rights, Rental Markets, and Land in China', Working Paper, Department of Agricultural and Applied Economics, University of WisconsinMadison.

Conning, J. and P. Deb. 2007. "Impact Evaluation for Land Property Rights Reforms." Unpublished manuscript, Department of Economics, City University of New York.

Couture, S. and A. Reynaud. 2008. "Multi-stand Forest Management under a Climatic Risk: Do Time and Risk Preferences Matter?" Environmental Modeling \& Assessment 13 (2): 181-193.

CSY (2009). China Statistical Yearbook 2009. China Statistics Press.

Dachang, L. 2001. "Tenure and Management of Non-State Forests in China since 1950: A Historical Review." Environmental History 6(2): 239-263.

Deininger, Klaus, Daniel Ayalew Ali and Tekie Alemu. 2011. "Impacts of Land Certification on Tenure Security, Investment, and Land Market Participation: Evidence from Ethiopia." Land Economics 87(2): 312-334.

de Janvry, A., K Emerick, M Gonzalez-Navarro, and E Sadoulet. 2015. "Delinking land rights from land use: Impact of certification on migration and land use in rural Mexico." American Economic Review 105(10): 3125-3149.

Do, Quy Toan and Lakshmi Iyer. 2008. "Land titling and rural transition in Vietnam." Economic Development and Cultural Change 56(3): 531-579.

Ellsworth, L. and A. White. 2004. Deeper Roots: Strengthening Community Tenure Security and Community Livelihoods. Ford Foundation.

Food and Agriculture Organization of the United Nations (FAO). 2010. "Global Forest Assessment Report 2010." FAO Forestry Paper 163. Rome. 165. Rome.

. 2011. "Reforming forest tenure: Issues, principles and process." FAO Forestry Paper

Frederick, S., G. Loewenstein and T. O'Donoghue. 2002. "Time Discounting and Time Preference: A Critical Review." Journal of Economic Literature 40 (2): 351-401. 
Godoy, R., M. Jacobson, J. De Castro, V. Aliaga, J. Romero and A. Davis. 1998. "The Role of Tenure Security and Private Time Preference in Neotropical Deforestation " Land Economics 74(2): 162-170.

Godoy, R., K. Kirby and D. Wilkie. 2001. "Tenure security, private time preference, and use of natural resources among lowland Bolivian Amerindians." Ecological Economics 38(1): 105118.

Goldstein, Markus and Christopher Udry. 2008. "The Profits of Power: Land Rights and Agricultural Investment in Ghana." Journal of Political Economy 116(6): 981-1022.

Grimm, M. and S. Klasen. 2015. "Migration Pressure, Tenure Security, and Agricultural Intensification: Evidence from Indonesia." Land Economics 91(3): 411-434.

Gordon, H. Scott. 1954. "The Economic Theory of a Common-Property Resource: The Fishery." Journal of Political Economy 62:124-142.

Hagos, F. and S. Holden. 2006. "Tenure security, resource poverty, public programs, and household plot-level conservation investments in the highlands of northern Ethiopia." Agricultural Economics 34: 183-196.

Hansen, B. and J. Bowers. 2008. "Covariate balance in simple, stratified and clustered comparative studies." Statistical Science 23: 219-236.

Hardin, Garrett. 1968. "The tragedy of the commons.” Science 13(162): 1243-48.

Harrison, G.W., Johnson, E., McInnes, M. M., and Ruström, E.E. 2005. "Temporal stability of estimates of risk aversion." Applied Financial Economic Letters 1(1):31-35.

Holden, S.T. and H. Johannes. 2002. Land Redistribution, Tenure Insecurity, and Intensity of Production: A Study of Farm Households in Southern Ethiopia. Land Economics 78(4)57390.

Holden, S., B. Shiferaw, and M. Wik. 1998. "Poverty, market imperfections and time preferences: of relevance for environmental policy?" Environment and Development Economics 2 (1):105-130.

Holden, S. T., K. Deininger, and H. Ghebru. 2009. "Impacts of Low-Cost Land Certification on Investment and Productivity." American Journal of Agricultural Economics 91 (2): 359-373.

Holden S.T., Yi Y., Jiang X., Xu J. 2013. Tenure Security and Investment Effects of Forest Tenure Reform in China. In: Holden S.T., Otsuka K., Deininger K. (eds) Land Tenure Reform in Asia and Africa. Palgrave Macmillan, London 
Holt, C. A. and S. K. Laury. 2002. "Risk Aversion and Incentive Effects." The American Economic Review 92 (5): 1644-1655.

Hyde, W. F., B. Belcher and J. Xu. 2003. China's Forests: Global Lessons from Market Reforms. Resources for the Future and Center for International Forestry Research, Washington, D.C.

Jacoby, Hanan G, Guo Li and Scott Rozelle. 2002. "Hazards of Expropriation: Tenure Insecurity and Investment in Rural China." The American Economic Review 95(5): 1420-1447.

Jagger, Pamela, M. K. Luckert, A. E. Duchelle, Jens Friis Lund, William D. Sunderlin. 2014. Tenure and Forest Income: Observations from a Global Study on Forests and Poverty. World Development, 64(S1): 43-55.

Johansson, Per Olov and Karl Gustaf Lofgren. 1985. The Economics of Forestry and Natural Resources. Oxford: Basil Blackwell. Pp. 264-273.

Kahneman, D. and A. Tversky. 1979. "Prospect Theory: An Analysis of Choice Under Risk." Econometrica 98(6): 1325-48.

Koszegi, Botond, and Matthew Rabin. 2009. "Reference-dependent consumption plans." The American Review 99(3): 909-936.

Larson, A., M. Brockhaus, W.D. Sunderlin, A. Duchelle, A. Babon, T. Dokken, T. Pham, I.A.P. Resosudarmo, G. Selaya, A. Awono, T.B. Huynh. 2013. "Land tenure and REDD+: The good, the bad and the ugly," Global Environmental Change 23(3): 678-689

Li, Jie, Marcus W. Feldman, Shuzhuo Li, and Gretchen C. Daily. 2011. "Rural household income and inequality under the Sloping Land Conversion Program in western China." PNAS. doi: $10.1073 /$ pnas. 1101018108

Liu, E. M. 2013. "Time to Change What to Sow: Risk Preferences and Technology Adoption Decisions of Cotton Farmers in China." The Review of Economics and Statistics 95(4): 13861403.

Liu, D. and Edmunds, D. 2003. 'Devolution as a Means of Expanding Local Forest Management in South China. Lessons from the Past 20 Years', in Hyde, W.F., Belcher, B. and Xu, J. (eds), China's Forests: Global Lessons from Market Reforms (Washington D.C. Resources for the Future Press).

Liu, Jinlong, and Zhao Lixia. 2009. "Have decollectivization and privatization contributed to sustainable forestry management and poverty alleviation in China?" Forestry Policy and Institutions Working Paper No. 23, Food and Agricultural Organization of the United Nations, Rome. 
Miao, G. and R. A. West. 2004. "Chinese collective forestlands: contributions and constraints." International Forestry Review 6 (3-4): 282-298.

Mekonnen A., Ghebru H., Holden S.T., Kassie M. 2013. The Impact of Land Certification on Tree Growing on Private Plots of Rural Households: Evidence from Ethiopia. In: Holden S.T., Otsuka K., Deininger K. (eds) Land Tenure Reform in Asia and Africa. Palgrave Macmillan, London

Meier, S. and C. Sprenger. 2010. Stability of Time Preferences. IZA Discussion Paper No. 4756 February 2010.

Newman, D. H. 2002. "Forestry's golden rule and the development of the optimal forest rotation literature." Journal of Forest Economics 8(1): 5-27.

Nielsen,U. 2001. "Poverty and Attitudes Towards Time and Risk - Experimental Evidence from Madagascar." Working Paper, Royal Veterinary and Agricultural University of Denmark.

Ong, Lynette H. Prosper or Perish: Credit and Fiscal Systems in Rural China. Ithaca, NY: Cornell University Press, 2012.

Ostrom, E. 1990. Governing the Commons: The Evolution of Institutions for Collective Action. Cambridge, Cambridge University Press.

Pattanayak, Subhrendu K. and Erin O. Sills. 2001. "Do tropical forests provide natural insurance? The microeconomics of non-timber forest product collection in the Brazilian Amazon." Land Economics 77(4): 595-612.

Place, Frank and Shem Migot-Adholla. 1998. "The economic effects of land registration for smallholder farms in Kenya: evidence from Nyeri and Kakamega Districts." Land Economics 74(3), 360-373

Prelec, D. 1998. "The Probability Weighting Function." Econometrica 66(3): 30.

Reed, W. J. (1984). "The Effects of the Risk of Fire on the Optimal Rotation of a Forest." Journal of Environmental Economics and Management 11, 180-190.

Reynaud, A. and Couture, S. 2012. Stability of risk preferences measures: results from a field experiment on French farmers. Theory and Decision 73(2):203-221.

Robinson, B.E., M.B. Holland, L. Naughton-Treves. 2014. "Does secure land tenure save forests? A meta-analysis of the relationship between land tenure and tropical deforestation." Global Environmental Change 29: 281-293.

Rozelle, S., Brandt, L., Gou, L. and Huang, J. (2002) 'Land Rights in China: Facts, Fictions, and Issues', China Journal, 47, 61-91. 
Sahm, C. (2007) How much does risk tolerance change? Federal Reserve Board, Washington, D.C.: Finance and Economic Discussion Series.

Sunderlin, W. D., A. Angelsen, B. Belcher, P. Burgers, R. Nasi, L. Santoso and S. Wunder. 2005. "Livelihoods, forests, and conservation in developing countries: An Overview." World Development 33(9): 1383-1402.

Sunderlin, W., Hatcher, J. and Liddle, M. 2008. "From Exclusion to Ownership: Challenges and Opportunities in Advancing Forest Tenure Reform." Rights and Resources Initiative: Washington, DC, USA.

Tahvonen, O. and M. Kallio. 2006. "Optimal Harvesting of Forest Age Classes Under Price Uncertainty and Risk Aversion." Natural Resource Modeling 19(4): 557-585.

Tanaka, T., C. F. Camerer and Q. Nguyen. 2010. "Risk and Time Preferences: Experimental and Household Survey Data from Vietnam.” American Economic Review 100(1): 557-571.

Tversky, A. and D. Kahneman. 1992. "Advances in Prospect Theory - Cummulative Representation of Uncertainty." Journal of Risk and Uncertainty 5(4): 297-323.

Walker, Robert, Charles H. Wood, David Skole, and Walter Chomentowski. "The Impact of Land Titling on Tropical Forest Resources." Linking People, Place, and Policy. Ed. Stephen J. Walsh, Ed. Kelley A. Crews-Meyer. US: Springer, 2002. 131-153.

Wang, X., E. Scalise and R Giovarelli. 2012. Ensuring that poor rural women benefit from forestland reforms in China: fieldwork findings and policy recommendations. Seattle, USA, Landsea Rural Development Institute.

White, A. and A. Martin. 2002. Who owns the World's Forests? Forest Tenure and Public Forests in Transition. Washington, D.C., Forest Trends.

Wooldridge, Jeffrey M. 2010. Econometric Analysis of Cross Section and Panel Data, Second Edition. The MIT Press: Cambridge, MA.

Xu, J. and X. Jiang 2009. "Collective Forest Tenure Reform in China: Outcomes and Implications." FIG-World Bank Conference on Land Governance in Support of the MDGs: Responding to New Challenges, Washington, D.C.

Xu, J., A. White and U. Lele. 2010. China's Forest Land Tenure Reforms. Rights and Resources Initiative, Washington, D.C.

Yesuf, M. and R.A. Bluffstone. 2009. "Poverty, Risk Aversion, and Path dependence in LowIncome Countries: Experimental Evidence from Ethiopia." American Journal of Agricultural Economics 91(4): 1022-1037. 
Tables

Table 1. Comparison of descriptive statistics of household and plot-level variables.

Household-level characteristics

\begin{tabular}{|c|c|c|c|c|c|c|c|c|c|c|}
\hline \multirow[b]{2}{*}{ Variable } & \multicolumn{5}{|c|}{ Households with at least one plot with certificate } & \multicolumn{5}{|c|}{ Households without any plots with certificate plot } \\
\hline & Obs & Mean & Std. Dev. & Min & Max & Obs & Mean & Std. Dev. & Min & Max \\
\hline Discounting & 26 & 0.14 & 0.24 & 0.001 & 0.737 & 61 & 0.13 & 0.26 & -0.001 & 0.737 \\
\hline Risk aversion & 26 & 0.40 & 0.36 & -0.400 & 0.950 & 61 & 0.40 & 0.36 & -0.400 & 0.950 \\
\hline Probability weight dummy & 26 & 0.72 & 0.27 & 0 & 1 & 61 & 0.71 & 0.28 & 0 & 1 \\
\hline $\begin{array}{l}\text { Total number of plots } \\
\text { managed by household*** }\end{array}$ & 26 & 4.85 & 2.95 & 0 & 12 & 61 & 2.77 & 2.19 & 0 & 10 \\
\hline $\begin{array}{l}\text { Household member is a } \\
\text { member of the communist } \\
\text { party in } 2000\end{array}$ & 25 & 0.23 & 0.43 & 0 & 1 & 58 & 0.18 & 0.39 & 0 & 1 \\
\hline $\begin{array}{l}\text { Value of livestock died } \\
\text { (1000 yuan) }\end{array}$ & 25 & 0.43 & 1.13 & 0 & 5.65 & 58 & 0.37 & 0.65 & 0 & 2.68 \\
\hline $\begin{array}{l}\text { Household asset value per } \\
\text { capita ( } 1000 \text { yuan) }\end{array}$ & 25 & 5.38 & 5.10 & 0.07 & 16.45 & 58 & 9.08 & 28.05 & 0 & 155.61 \\
\hline
\end{tabular}

\section{Plot-level characteristics}

\begin{tabular}{|c|c|c|c|c|c|c|c|c|c|c|}
\hline \multirow[b]{2}{*}{ Variable } & \multicolumn{5}{|c|}{ Plots with certificate } & \multicolumn{5}{|c|}{ Plots without certificate } \\
\hline & Obs & Mean & Std. Dev. & Min & Max & Obs & Mean & Std. Dev. & Min & Max \\
\hline Plot has a slope $>25$ degrees & 88 & 0.59 & 0.49 & 0 & 1 & 207 & 0.50 & 0.50 & 0 & 1 \\
\hline Plot area (ha) & 75 & 1.23 & 3.90 & 0.02 & 26.67 & 145 & 0.79 & 2.12 & 0.01 & 20 \\
\hline Distance to home $(\mathrm{km})$ & 75 & 1.45 & 1.39 & 0.01 & 10 & 145 & 1.43 & 1.31 & 0 & 10 \\
\hline Distance to road $(\mathrm{km})$ & 75 & 0.84 & 1.11 & 0 & 7 & 145 & 0.90 & 1.00 & 0 & 8 \\
\hline Bamboo & 88 & 0.32 & 0.47 & 0 & 1 & 207 & 0.40 & 0.49 & 0 & 1 \\
\hline
\end{tabular}

Notes: Statistical significance is evaluated for each variable using a two-tailed t-test for difference-in-means. $*, * *$, and $* * *$ denote $\mathrm{p}<0.10, \mathrm{p}<0.05$, and $\mathrm{p}<0.01$, respectively. Table A2 in the Appendix gives the differences in means with p-values and confidence intervals. The t-test for number of plots is included for consistency but is not an appropriate test of sample balance due to base rate neglect. Under the null hypothesis of independent assignment of plots into treatment, households managing multiple plots have a higher probability of having at least one plot treated. We conducted non-parametric simulation testing and found the correct $p$-value to be 0.805 . These findings are described in Section 2 of the online Appendix. 
Table 2. Parameter estimates from plot fixed effect linear probability model.

\begin{tabular}{|c|c|c|c|c|}
\hline & \multicolumn{4}{|c|}{$\begin{array}{l}\text { Dependent Variable: Whether or not tree was harvested } \\
\text { on plot } i \text { in year } t\end{array}$} \\
\hline VARIABLES & $\begin{array}{c}(1) \\
\text { Plot FE }\end{array}$ & $\begin{array}{l}\text { (2) } \\
\text { Plot FE with } \\
\text { risk }\end{array}$ & $\begin{array}{l}(3) \\
\text { Plot FE with } \\
\text { time }\end{array}$ & $\begin{array}{c}\text { (4) } \\
\text { Plot FE with } \\
\text { time and risk }\end{array}$ \\
\hline Treatment & $\begin{array}{l}-0.121 * \\
(-1.722)\end{array}$ & $\begin{array}{l}0.317 * * \\
(2.486)\end{array}$ & $\begin{array}{l}-0.157^{* *} \\
(-1.998)\end{array}$ & $\begin{array}{l}0.323 * * \\
(2.409)\end{array}$ \\
\hline Risk aversion $\mathrm{x}$ Treatment & & $\begin{array}{c}-0.744 * * * \\
(-4.872)\end{array}$ & & $\begin{array}{c}-0.756 * * * \\
(-4.323)\end{array}$ \\
\hline Loss aversion $\mathrm{x}$ Treatment & & $\begin{array}{l}0.0424 * * * \\
(5.107)\end{array}$ & & $\begin{array}{l}0.0435 * * * \\
(4.532)\end{array}$ \\
\hline $\begin{array}{l}\text { Probability weight dummy } x \\
\text { Treatment }\end{array}$ & & $\begin{array}{c}-0.364 * * * \\
(-2.938)\end{array}$ & & $\begin{array}{c}-0.363 * * * \\
(-2.916)\end{array}$ \\
\hline Discount rate $\mathrm{x}$ Treatment & & & $\begin{array}{c}0.277 \\
(1.613)\end{array}$ & $\begin{array}{l}-0.0501 \\
(-0.268)\end{array}$ \\
\hline Year $2008(=1)$ & $\begin{array}{c}-0.140 * * * \\
(-2.966)\end{array}$ & $\begin{array}{c}-0.140 * * * \\
(-2.959)\end{array}$ & $\begin{array}{l}-0.140 * * * \\
(-2.964)\end{array}$ & $\begin{array}{c}-0.140 * * * \\
(-2.956)\end{array}$ \\
\hline Constant & $\begin{array}{l}0.393 * * * \\
(21.47)\end{array}$ & $\begin{array}{l}0.393 * * * \\
(21.84)\end{array}$ & $\begin{array}{l}0.393 * * * \\
(21.49)\end{array}$ & $\begin{array}{l}0.393 * * * \\
(21.82)\end{array}$ \\
\hline Observations & 590 & 590 & 590 & 590 \\
\hline Number of unique plots & 295 & 295 & 295 & 295 \\
\hline Adjusted R-squared & 0.077 & 0.107 & 0.078 & 0.106 \\
\hline
\end{tabular}

Notes: Plot-level fixed effects are not shown. Cluster robust t-statistics are in parentheses. ${ }^{* * *} \mathrm{p}<0.01,{ }^{* *} \mathrm{p}<0.05,{ }^{*} \mathrm{p}<0.1$. Note that Treatment refers only to observations that are both in the treatment group and in the year 2008. 
Table 3: Implied certification effect.

Panel A: Probability weighting dummy $=0$

\begin{tabular}{|c|c|c|c|c|}
\hline & & Risk & ersion & \\
\hline & & $25^{\text {th }}$ percentile & $50^{\text {th }}$ percentile & $75^{\text {th }}$ percentile \\
\hline & $25^{\text {th }}$ percentile & 0.176 & 0.025 & -0.126 \\
\hline & & (1.54) & $(0.22)$ & $(1.08)$ \\
\hline & $50^{\text {th }}$ percentile & $0.255^{* *}$ & 0.104 & -0.047 \\
\hline$\cdot \frac{0}{\infty}$ & & $(2.15)$ & $(0.94)$ & $(0.41)$ \\
\hline \& & $75^{\text {th }}$ percentile & $0.932 * * *$ & $0.780^{* * *}$ & $0.629 * * *$ \\
\hline 表 & & & & \\
\hline
\end{tabular}

Panel B: Probability weighting dummy $=1$

\begin{tabular}{|c|c|c|c|c|}
\hline & \multicolumn{4}{|c|}{ Risk aversion } \\
\hline \multirow[b]{4}{*}{ b } & & $25^{\text {th }}$ percentile & $50^{\text {th }}$ percentile & $75^{\text {th }}$ percentile \\
\hline & $25^{\text {th }}$ percentile & $\begin{array}{c}-0.187 * * \\
(2.26)\end{array}$ & $\begin{array}{c}-0.338 * * * \\
(3.83)\end{array}$ & $\begin{array}{c}-0.489 * * * \\
(4.61)\end{array}$ \\
\hline & $50^{\text {th }}$ percentile & $\begin{array}{l}-0.108 \\
(1.37)\end{array}$ & $\begin{array}{c}-0.259 * * * \\
(3.27)\end{array}$ & $\begin{array}{c}-0.410^{* * *} \\
(4.37)\end{array}$ \\
\hline & $75^{\text {th }}$ percentile & $\begin{array}{c}0.569 * * * \\
(3.54)\end{array}$ & $\begin{array}{c}0.418^{* * *} \\
(3.12)\end{array}$ & $\begin{array}{c}0.267^{* *} \\
(2.37)\end{array}$ \\
\hline
\end{tabular}

Notes: T-statistics shown in parenthesis. $* * * p<0.01$ and $* * p<0.05$. Implied certification effect was evaluated at the $25^{\text {th }}, 50^{\text {th }}$, and the $75^{\text {th }}$ percentiles of the risk aversion $(0.20,0.40,0.60)$ and loss aversion $(0.23,2.05,17.60)$ parameters for when probability weighting dummy is equal to 0 (Panel A) and to 1 (Panel B). The estimated discount rate was fixed at the mean (0.11). 
Table 4. Coefficient estimates from a descriptive regression for baseline year harvest (2000).

\begin{tabular}{|c|c|c|c|}
\hline & \multicolumn{3}{|c|}{ Dependent variable: Whether or not tree was harvested in baseline year } \\
\hline VARIABLES & $\begin{array}{c}\text { (1) } \\
\text { Village FE } \\
\text { baseline year }\end{array}$ & $\begin{array}{c}\text { (2) } \\
\text { Village FE with } \\
\text { household controls } \\
\text { baseline year }\end{array}$ & $\begin{array}{c}\text { (3) } \\
\text { Village FE with household and } \\
\text { plot controls } \\
\text { baseline year }\end{array}$ \\
\hline Discounting & $\begin{array}{c}-0.110 \\
(-1.286)\end{array}$ & $\begin{array}{l}-0.0933 \\
(-1.058)\end{array}$ & $\begin{array}{l}-0.0276 \\
(-0.352)\end{array}$ \\
\hline Risk aversion & $\begin{array}{l}0.0122 \\
(0.183)\end{array}$ & $\begin{array}{l}0.0240 \\
(0.348)\end{array}$ & $\begin{array}{l}0.117 * * \\
(2.085)\end{array}$ \\
\hline Probability weight dummy & $\begin{array}{c}-0.00578 * \\
(-1.730) \\
0.0740 \\
(1.400)\end{array}$ & $\begin{array}{c}-0.00478 \\
(-1.435) \\
0.165 * * * \\
(3.170)\end{array}$ & $\begin{array}{c}-0.0102 * * * \\
(-3.536) \\
0.0959 * * \\
(1.990)\end{array}$ \\
\hline $\begin{array}{l}\text { Plot has a slope }>25 \\
\text { degrees }\end{array}$ & & & $\begin{array}{l}0.0194 \\
(0.483)\end{array}$ \\
\hline Distance plot to home $(\mathrm{km})$ & & & $\begin{array}{l}0.0104 \\
(0.669)\end{array}$ \\
\hline Distance plot to road $(\mathrm{km})$ & & & $\begin{array}{c}-0.00879 \\
(-0.476)\end{array}$ \\
\hline Bamboo $(=1)$ & & & $\begin{array}{c}0.176^{* * * *} \\
(4.585)\end{array}$ \\
\hline $\begin{array}{l}\text { Total number of plots } \\
\text { managed by households }\end{array}$ & & $\begin{array}{c}-0.00854 \\
(-1.060)\end{array}$ & -0.00345 \\
\hline $\begin{array}{l}\text { Household member is a } \\
\text { village cadre in } 2000(=1)\end{array}$ & & $\begin{array}{c}0.123 \\
(0.938)\end{array}$ & $\begin{array}{c}0.151 \\
(1.212)\end{array}$ \\
\hline $\begin{array}{l}\text { Household member is a } \\
\text { member of communist } \\
\text { party in } 2000(=1)\end{array}$ & & $\begin{array}{l}0.0742 \\
(1.286)\end{array}$ & $\begin{array}{l}0.0523 \\
(0.938)\end{array}$ \\
\hline $\begin{array}{l}\text { Value of livestock died in } \\
2000 \text { (1000 yuan) }\end{array}$ & & $\begin{array}{c}0.0814 * * \\
(2.122)\end{array}$ & $\begin{array}{l}0.0608 * \\
(1.767)\end{array}$ \\
\hline $\begin{array}{l}\text { Household asset value per } \\
\text { capita in } 2000 \text { ( } 1000 \text { yuan) }\end{array}$ & & $\begin{array}{c}-0.000356 \\
(-0.866)\end{array}$ & $\begin{array}{c}-0.000227 \\
(-0.576)\end{array}$ \\
\hline Constant & $\begin{array}{c}0.508 * * * \\
(5.638)\end{array}$ & $\begin{array}{c}0.402 * * * \\
(3.977)\end{array}$ & $\begin{array}{c}0.239 * * \\
(2.427)\end{array}$ \\
\hline Observations & 590 & 461 & 438 \\
\hline Adjusted R-squared & 0.064 & 0.173 & 0.181 \\
\hline Village FE & Yes & Yes & Yes \\
\hline Household FE & No & No & No \\
\hline Plot FE & No & No & No \\
\hline
\end{tabular}

Cluster robust t-statistics in parentheses. The models were estimated using a linear probability model. $* * * \mathrm{p}<0.01, * * \mathrm{p}<0.05, * \mathrm{p}<0.1$ 
Table 5. Summary of results compared with hypotheses

\begin{tabular}{|c|c|c|c|}
\hline Effect & Comparative Static & Prediction & Empirical estimates \\
\hline Expropriation risk & $\partial H_{1}^{*} / \partial p_{L}$ & Ambiguous/Increase? & Increase \\
\hline \multirow[t]{2}{*}{ Probability weights } & $\partial H_{1}^{*} / \partial \alpha$ & Ambiguous & Increase \\
\hline & $\partial^{2} H_{1}^{*} / \partial \alpha \partial p_{L}$ & Same as expropriation risk & Increase (same as expropriation risk) \\
\hline \multirow[t]{2}{*}{ Risk aversion } & $\partial H_{1}^{*} / \partial \sigma$ & Ambiguous & Increase \\
\hline & $\partial^{2} H_{1}^{*} / \partial \sigma \partial p_{L}$ & Ambiguous & Increase \\
\hline \multirow[t]{2}{*}{ Loss aversion } & $\partial H_{1}^{*} / \partial \lambda$ & Increase & Decrease \\
\hline & $\partial^{2} H_{1}^{*} / \partial \lambda \partial p_{L}$ & $\begin{array}{l}\text { Opposite of expropriation } \\
\text { risk }\end{array}$ & Decrease (opposite of expropriation risk) \\
\hline \multirow[t]{2}{*}{ Discounting } & $\partial H_{1}^{*} / \partial \rho$ & Increase & Not significant \\
\hline & $\partial^{2} H_{1}^{*} / \partial \rho \partial p_{L}$ & Same as expropriation risk & Not significant \\
\hline
\end{tabular}

Notes: Results for the expropriation risk and its interaction with the preferences are based on the plot level fixed effects models reported in Table 2. The empirical results of the direct effects of preference variables are based on the descriptive regression of the baseline year harvest reported in Table 4 . Since $p_{L}$ in the theoretical model is the probability of expropriation, the sign of the empirical estimates of the certification treatment effect is opposite. 
${ }^{1}$ Since the duration of the certificates under the reform were mostly good for 70 years, households are likely to
consider this as a one-time reform. Although, we do not have data on households' expectations for additional waves
of reform, we conjecture that the issuance of the certificates perceived as pivotal and is likely to have a lasting
impact on household behavior and livelihood. That said, if there were any possibility of potential anticipation of
future reforms, the bias would be in the direction of attenuating the results. We thank a referee for this point of view.

${ }^{2}$ The model assumes that agents' only income is from forest harvesting. According to our data, most households in our sample participate in income generating activities in addition to forestry such as farming and off-farm work. Therefore, it is possible that the harvesting decision is endogenous to other income generating activities. This factor would become important if the labor market were constrained, but this is not the case in our study area. Examining the impact on a whole range of outcomes would be beyond the scope of this paper.

${ }^{3}$ We acknowledge that there may be recall bias since six years is not a trivial amount of time. We also acknowledge the potential of strategic responses bias since the first round of survey in 2006 was conducted after the reform had started. We took several steps to reduce this bias during data collection. The survey questions were phrased so that we ask for facts and decisions instead of asking for what was the impact of the reform; we trained the enumerators to look for any inconsistencies or take note of any irregular responses. The survey was about 90 minutes long, and it would have been difficult for households to understand that we were analyzing changes in harvesting decisions over time.

${ }^{4}$ From the original 104 households, 17 households were dropped from the regressions: 1 household did not participate in the risk and time experiments; 3 households had discrepancies in the plots across years; 3 households did not manage the plots prior to the treatment year; 9 households reported only having an old type of forest certificate which was different from the one given under the reform in question; 1 household with missing data for distance variables.

${ }^{5}$ We acknowledge that the binary harvest variable is coarse. Ideally, we would want to understand the extent of the harvest as the referee suggests, but at the time of the survey design the research team found it difficult for rural farmers to give information with accuracy. Importantly, the average size of the forest plots in our sample is 0.94 ha, which is very small compared to the average size of privately-owned forests in major forest regions cross the tropics (191 hectares, Jagger et al. 2014). Under this circumstance, the binary harvest variable may be adequate to capture harvesting behavior.

${ }^{6}$ Prospect theory assumes that people overweight unlikely events, i.e., events with small probabilities (Tversky and Kahneman 1992).

${ }^{7}$ We thank a referee for this suggestion.

${ }^{8}$ To clarify, we did not receive precise plot-level information about the timing of the certification relative to the timing of harvest in 2005. There were two types of certification information: either we were given only the year of certification or we were given the year and the month of certification. In neither case did we have the 2005 harvest behavior broken down by the month(s) when it occurred. Some plots were certified at times in late 2004 or in 2006 so we clearly know whether they were certified or not prior to the 2005 harvest, other plots we had year-month data in 2005 but not the timing that harvest was conducted, and still other plots had only data that they were certified in 2005 but without the month of certification. While potentially some of these data could have been corrected/recovered after the fact, we found it unlikely that all of it could have been restored so we chose to drop our 2005 data from the analysis.

${ }^{9}$ We estimate this equation as a linear probability model in fixed effects form. We choose a linear probability model over non-linear Probit or Logit models for two reasons. First, plot fixed effects cannot be easily included in nonlinear discrete-choice models in a flexible manner. Fixed plot effects cannot be included in a Probit model due to the incidental parameters problem, and fixed effects Logit models do not allow for calculation of marginal 
effects since marginal effects are non-linear functions of the un-estimated fixed effects (see Wooldridge 2010, Ch. 15). In contrast, the fixed effect linear probability model is robust to any distributional assumption of the plot effect - as the plot effect is entirely differenced out of the model. Second, while linear probability models have the obvious weakness of not constraining probabilities between zero and one, many researchers have shown that they give almost identical marginal effects at the mean of the data as do non-linear Probit or Logit models with similar identifying assumptions (see Angrist and Pischke 2009, Ch. 3; Wooldridge 2010, Ch. 15). Since our primary interest is in estimating marginal effects, we choose the more flexible fixed effects linear probability model for estimation.

${ }^{10}$ The implied certification effects and the standard errors were computed using lincom in stata.

${ }^{11}$ The results are available from the authors upon request. 